\title{
Green Practice and Firm Sustainability Strategy - An Analysis of Recent Literature in Petrochemical Industry
}

\author{
Yuary Farradia, Hendro Sasongko, Abdul Talib Bon
}

\begin{abstract}
Green effort and environmental responsiveness towards society go a long way for business sustenance. Studies shows that going green has helped organizations manage risks more effectively, enter new markets, improve their product quality, enhance the processes, use resources more efficiently with the help of stimulating innovation to adopt green management practices at the workplace. Environmental strategy and green efforts are influenced by the degree of company's commitment towards sustainability. Sustainability comprises three pillars of social, environmental, and economic aspects. Petrochemical industry has a great interrelated complex impact on social and economic development of societies and adverse impact on almost all environmental aspects and resource depletion in many countries, which make sustainability a crucial issue for petrochemical industries. This paper offers an analysis of sustainability strategy of petrochemical industry relate to green practice which include 8 research articles published consist of the country initiatives to implement green practices strategy toward sustainability between 2014 to 2018 . In conclusion, sustainability considerations had started to be taken into account in petrochemical industry, due to scarcity of natural resources and importance of this industry in development in one hand and environmental damage caused by this industry on the other hand.
\end{abstract}

Index Terms: Green Practice, Firm Sustainability Strategy, Petrochemical.

\section{INTRODUCTION}

The upstream chemical industry is the most important in the value chain as it provides all the synthetic materials needed for further processing [1] and it has been known that the upstream chemical industry is the petrochemical industry. The petrochemical industry goal for a development strategy is sustainability or sustainable development. Moreover, environmental strategy and green efforts are influenced by the degree of company's commitment towards sustainability [2].

Sustainable practices of the companies and supply chains are relevant and should be aligned with triple bottom dimensions. Sustainability always be the focus of business because many companies worldwide have used it to generate top line growth while simultaneously cutting costs to achieve meaningful bottom-line returns, means that sustainability is not only about environmental benefits, but it's also about profitability [3]. Green management practice which is becoming the new norm and an organization of today cannot

Revised Manuscript Received on April 25, 2019.

Yuary Farradia, Faculty of Technology Management and Business, Universiti Tun Hussein Onn Malaysia, Batu Pahat, Malaysia.

Hendro Sasongko, Faculty of Economics, Pakuan University Bogor, Indonesia.

Abdul Talib Bon, Faculty of Technology Management and Business, Universiti Tun Hussein Onn Malaysia, Batu Pahat, Malaysia. succeed in the present competitive environment if it does not follow the current green management practices effectively and efficiently [4]. Besides improving the public image of the organization, going greener help improve the relationship of the organization with its stakeholders like customers, suppliers, government agencies, and the media. With increase in concern about global issues, many organizations are trying to reduce their impact on the environment. Green initiatives can also reduce costs. The reduced costs depend on the size of the organization and the steps taken to reduce energy consumption.

\section{LITERATURE REVIEW}

A Chemical and petrochemical manufactures are the second largest energy consuming manufacturing sector in the world and accounts for almost $5 \%$ of global GHG emissions. It includes direct (on-site) $\mathrm{CO}_{2}$ emissions from fossil fuel combustion, indirect emissions from electricity consumed during production and release of non $\mathrm{CO}_{2}$ gases from various industrial processes [5]. As the world becomes increasingly concerned about climate change and begins shifting consumption to more renewable resources, petrochemical manufacturers will either be seen as contributors to a growing problem or leaders in mitigating a global environmental crisis.

As the consumers are getting more and more concerned about the environment, they perceive organization adopting green management practices better as compared to organization that are causing harm to the environment, thereby improving the public image of the organization [4]. Hence, green practices adopted in the organization will improve public image, increases profit in the organization, better employee retention rate and stimulates innovation. In addition, she also declared that going green has helped organizations manage risks more effectively, enter new markets, improve their product quality, enhance the processes, use resources more efficiently with the help of stimulating innovation to adopt green management practices at the workplace.

The economic, social and environmental dimensions are directly related to sustainable development in organizations and are described in [6]: the economic point of view of sustainability provides that the role of business in society is to be economically viable, i.e. to return to in- vestment by means of private capital. In social terms, the company must provide the best working conditions, taking into account cultural differences and providing opportunity to the disabled in general and the participation on of it learerd En in'socio-cultural activities. 


\section{Green Practice and Firm Sustainability Strategy - An Analysis of Recent Literature in Petrochemical Industry in Indonesia}

From an environmental point of view, the organization should seek eco-efficiency of its production processes, adopt cleaner production, development an organizational environmental culture and adopt an environmentally responsible attitude. Prior study on sustainability dimension found that two dimension of sustainability could set company positioning in terms of environmental sustainability among its competitors and provides strategic guidelines [7]. The sustainability progress dimension assesses the stage of the corporate social responsibility on environmental culture in an organization. On the other hand, the environmental sustainability dimension indicates firm involvement in corporate social responsibility with environmental practices.

\section{DATA COLLECTION}

This study is an analysis of various literatures about green practice and firm sustainability strategy within Petrochemical Industry, including: Emerald, Springer, Science Direct, Elsevier, and others. The search engines like Google Scholar and Scopus were also used to make sure coverage of publications in other databases. Through systematic literature review, focus on petrochemical only, this study identified 8 latest articles published within last four years between 2014 to 2018.

Combination of keywords were used related to petrochemical green supply chain management practices, the keywords used were; petrochemical, green purchasing, eco design, green supply chain management, supply chain), and for performance outcomes the keywords used were; performance, outcome and benefit. The search resulted in 8 petrochemical sustainability articles published between 2014 and first quarter of 2018. The full text of the articles was studied carefully, and selected for review.

\section{GREEN PRACTICE IN PETROCHEMICAL INDUSTRY}

Green practice at Tianjin Petrochemical in China was based on their three-year Action Plan, with the objectives were : to achieve the goal of becoming the first batch of green enterprises of the petrochemical industry within the year; to create a first-class green enterprise in the domestic petrochemical industry in 2019; to become a benchmark for green development in 2020, and to create a world-class green business. As the result after continuous treatment was the total amount of major pollutants in the company was cut by $55 \%$, and the effluent index has reached the most advanced level in China while all gasoline and diesel has reached the standards of national VI quality, which exceeded in advance goals set by the Twelfth Five-Year Plan issued by the state, Tianjin Municipality, and Sinopec.

Other country, like the Indonesia government also put high effort on the integrated petrochemical industry development by strengthening research and development toward green industry of petrochemical industry in order to create more market potential as well as to achieve the sustainability [8]. Green industry standardization has started be implemented by some of the Petrochemical Producers. The green industry concept is in line with the effort of driving the organizations to focus on driving excellence through all areas of the organization from supply chain to operations, to channel management to sales and marketing, R\&D and finance, toward firm sustainability.

On the other hand, green practice toward firm sustainability in farabi petrochemical in Saudi Arabic is considered as a core value at Farabi Petrochemical Company business culture [9]. Farabi petrochemical company business integrates the green supply chain management into the work environment through designing robust work processes that prevent harm to onsite working people, community and environment, by highly trained and developed talents. Moreover, petrochemical in Saudi Arabic goal in 2023 focuses on 3 strategies: operational strategy, health and safety of people and Social Commitments [9]. Under Operational strategy we have set priorities for some key indicators including $\mathrm{CO} 2$ equivalent emission intensity reduction.

Latest study on other country such as India indicated that petrochemical industry sector contains large scale companies where technologies were imported from foreign [10]. Therefore, India needs a legal autonomous institution to regulate this sector trough effective regulation due to natural resources are wealth for a country, particularly when such resources are scarce in quantity.

Iran's petrochemical industry has proposed a new model for technology strategy formulation as the result of an integrated and systematic hybrid of existing models presented in literature of technology strategy. This method is the most appropriate one because it decreases dependence on natural resources and it uses biological wastewater treatments [11].

The key driver for green practice and firm sustainability strategy initiatives is summarized at Table 1 .

\section{DISCUSSION}

The green industry concept is in line with the effort of driving the organizations to focus on driving excellence through all areas of the organization from supply chain to operations, to channel management to sales and marketing, R\&D and finance, toward firm sustainability. Sustainability means being able to satisfy current needs without compromising the possibility for future generations to satisfy their own needs [19]. Thus it is about the proper use of natural resources by taking into consideration resource consumption on both present and future quality of life [12]. Iranian petrochemical industry objective is to obtain optimal energy consumption management from the one hand and maximum profitability and productivity of these resources, on the other hand [13].

Whilst Indian Petrochemical industry needs the green approach and development supported by environmental strategies, and provides directions to companies in terms of strategies to invest in order to be competitive in global market [2].

Several Gulf petrochemical manufacturers have already begun sustainability-driven cost- reduction initiatives which could be classified into the following four categories: Improve internal manufacturing process to optimize yields; reduce waste from the process of direct and indirect inputs; Increase energy efficiency and Improve supply chain efficiency [18]. 
Table 1: Key Driver For Green Practice and Firm Sustainability Strategy Initiatives

\begin{tabular}{|c|c|c|}
\hline Country & $\begin{array}{l}\text { Green Practice and Firm Sustainability } \\
\text { Strategy }\end{array}$ & $\begin{array}{l}\text { Sourc } \\
\text { e }\end{array}$ \\
\hline India & $\begin{array}{l}\text {-Extraction and production cost subject to } \\
\text { environmental pricing principles. } \\
\text {-Effective regulation through a Proper } \\
\text { institution: Natural resources are wealth for a } \\
\text { country, particularly when such resources are } \\
\text { scarce in quantity. }\end{array}$ & $\begin{array}{l}\text { Ref } \\
{[10]}\end{array}$ \\
\hline Thailand & $\begin{array}{l}\text { Production of environmentally friendly } \\
\text { bioplastics based on domestic biomass inputs }\end{array}$ & $\begin{array}{l}\text { Ref } \\
{[13]}\end{array}$ \\
\hline Iran & $\begin{array}{l}\text {-All aspects of sustainability, considering } \\
\text { materials (raw material, intermediate material, } \\
\text { and products, by products, emission, and } \\
\text { waste), the processes including synthesis, } \\
\text { separation, refinement, handling and storage } \\
\text { of products, reducing emission level, and } \\
\text { finally technology and infrastructure aspects. } \\
\text {-Process, procedures, and services should be } \\
\text { designed to be clean and green and promote } \\
\text { sustainability for all stakeholders including } \\
\text { customers, community, environment, and } \\
\text { value sustainability as core values of the } \\
\text { business. }\end{array}$ & $\begin{array}{l}\text { Ref } \\
{[14]}\end{array}$ \\
\hline Global & $\begin{array}{l}\text { The production methods of ethylene will be } \\
\text { based on the cheapest raw material, lowest } \\
\text { energy consumption, }\end{array}$ & $\begin{array}{l}\text { Ref } \\
{[15]}\end{array}$ \\
\hline $\begin{array}{l}\text { Global - at } \\
\text { Refining and } \\
\text { petrochemical } \\
\text { industry }\end{array}$ & $\begin{array}{l}\text { Integrated approach of environmental issues in } \\
\text { industrial complex become the basis for } \\
\text { situation of refining and petrochemical } \\
\text { industries against environmental conditions. } \\
\text {-Sustainability and environmental issues are } \\
\text { becoming important components of } \\
\text { competitive advantage and positive image of } \\
\text { petrochemical industries. }\end{array}$ & $\begin{array}{l}\text { Ref } \\
{[16]}\end{array}$ \\
\hline $\begin{array}{l}\text { Saudi Arabia, } \\
\text { Kuwait, the } \\
\text { United Arab } \\
\text { Emirates, } \\
\text { Qatar, Bahrain, } \\
\text { and Oman } \\
\text { (Gulf } \\
\text { Corporation } \\
\text { Council's } \\
\text { countries - } \\
\text { Gulf } \\
\text { Petrochemical } \\
\text { Manufacturers } \\
\text { ) }\end{array}$ & $\begin{array}{l}\text { 1. Revenue generation such as Create new } \\
\text { environment friendly products, Strengthen } \\
\text { pricing position and Develop new revenue } \\
\text { streams, } 2 \text {.Brand enhancement such } \\
\text { as to improve competitive differentiation, to } \\
\text { increase positive messaging. } \\
\begin{array}{l}\text { reduction such as eliminate waste, Improve } \\
\text { production efficiencies and } \\
\text { regulatory compliance }\end{array}\end{array}$ & $\operatorname{Ref}[3]$ \\
\hline India & $\begin{array}{l}\text { Protect environment by mitigating resource } \\
\text { scarcity, reducing energy consumption and } \\
\text { curbing waste disposal and reduce production } \\
\text { cost can be achieved through eco-efficiencies } \\
\text { and improved resource management systems. }\end{array}$ & $\operatorname{Ref}[2]$ \\
\hline Global & $\begin{array}{l}\text { There are eight types of sustainable business } \\
\text { such as: 1.maximizing material productivity } \\
\text { and energy efficiency, 2.Creating value from } \\
\text { waste, 3.Substitution with renewables and } \\
\text { natural processes, } 4 \text {. Limits to growth, which is } \\
\text { associated with non-renewable resources and } \\
\text { current production systems, 5.Delivering } \\
\text { functionality, rather than ownership, } 6 . \\
\text { Adopting a stewardship role, 7.Encouraging } \\
\text { sufficiency, re-purposing the business for } \\
\text { society/ environment, and finally } 8 \text {. } \\
\text { Developing scale-up solutions which means } \\
\text { delivering sustainable solutions at a large scale } \\
\text { to maximize benefits for society and the } \\
\text { environment }\end{array}$ & $\begin{array}{l}\text { Ref } \\
{[17]}\end{array}$ \\
\hline
\end{tabular}

\section{CONCLUSION}

In conclusion, sustainability considerations should be taken into account in petrochemical industry, considering scarcity of natural resources and importance of this industry in development in one hand and environmental damage caused by this industry on the other hand.

Sustainability can also be a vehicle to build brand loyalty. Petrochemical-based products often bear the brunt of public criticism regarding environmental and biological impacts [18]

\section{ACKNOWLEDGMENT}

Thank you for the Faculty of Technology and Management Universiti Tun Hussein Onn for the literatures access provided.

Thank you for Faculty of Economics Universitas Pakuan for the support

\section{REFERENCES}

1. S. Evans, S. Fokeer and G. Rezonja. Sustainable assessment of chemical industries for policy advice. The case of The Philippines, Thailand, Indonesia and Vietnam. London: Research, Statistics and Industrial Policy, 2015.

2. D. Khastagir and M. Roy. "Environment Responsiveness of Petrochemical Organisation in India." European Journal of Business and Management, vol.6, no.2, pp. 199-220, 2014.

3. R. Rajala, M. Westerlund and T. Lampikoski. "Environmental sustainability in industrial manufacturing: re-examining the greening of Interface's business model." Journal of Cleaner Production, vol. 115, pp. 52-61, 2016.

4. M. Goyal. "Future Outlook of Green Management Practies." Journal of Business Management, vol. 14, no. 6, 68-72, 2013.

5. K. A. Baumert. Navigating the Numbers: Greenhouse Gas Data and International Climate Policy, Washington DC: World Resources institute, 2005.

6. R. Dias, "Environmental management: Social responsibility and sustainability." São Paulo: Atlas Publisher, 2009.

7. T. Menichini and F. Rosati. "A managerial tool for environmental sustainability.” APCBEE procedia, vol. 5, pp. 551-556, 2013.

8. Ministry of the State Secretariat. Indonesia Development Regulation, 2015.

9. Farabi sustainability annual report. Farabi Petrochemical Company, 2013.

10. M. H. Kunroo and K. Soni. "Petrochemical Industry in India: Determinants, Challenges and Opportunities." Progress Petrochem Science. vol. 1, no. 2, pp. 1-5, 2018.

11. M. Ebrahimi, A. M. Baerz, S. H. K. Hosseini and A. Azar. "A new model of petrochemical technology strategic planning." International Journal of Business Administration. vol. 4, no. 2, 1-10, 2013.

12. J. Robinson, "Squaring the circle? Some thoughts on the idea of sustainable development." Ecological economics, vol. 48, no. 4, pp. 369-384, 2004.

13. R. Leingchan. Petrochemical Industry. Thailand Industry Outlook, 2017.

14. A. Aryansl, J. Ghodousi, R. Arimandi and N. Mansouri. "Components of sustainability considerations in management of petrochemical industries." Environmental Monitoring and Assessment, vol.189, no. 6, pp. 274-283.

15. A.Alshammari, A.A. Bagabas, E.N Kalevaru. Production of Ethylene and its Commercial Importance in the Global Market. IGI Global. DOI: 10.4018/978-1-4666-9975-5.ch004.2016

16. A. Kaminski. "Integrated approach of environmental issues in industrial complex treated as complicated operated machine." Journal of KONES, vol. 22, no. 2, pp. 110-114, 2015.

17. N.M.P. Bocken, S.W. Short, P. Rana, S. Evans. A literature and practice review to develop sustainable business model archetypes. Journal of Cleaner Production. 65, 42-56. 2014

18. A.T. Kearney. Environmentally Sustainable GCC Petrochemicals. A.T Kearney, Inc. 2010.

19. World Commision on Environment and $\$ g^{y} y^{\text {and Engine }}$. Future. Oxford, University Press. 19 